\title{
Review Article \\ Syngas Generation from Methane Using a Chemical-Looping Concept: A Review of Oxygen Carriers
}

\author{
Kongzhai Li, ${ }^{1,2}$ Hua Wang, ${ }^{1}$ and Yonggang Wei ${ }^{1}$ \\ ${ }^{1}$ Engineering Research Center of Metallurgical Energy Conservation and Emission Reduction, \\ Kunming University of Science and Technology, Ministry of Education, Kunming, Yunnan 650093, China \\ ${ }^{2}$ Faculty of Metallurgy and Energy Engineering, Kunming University of Science and Technology, Room 217, \\ Kunming, Yunnan 650093, China
}

Correspondence should be addressed to Kongzhai Li; lkz_514@yahoo.com.cn

Received 30 June 2012; Accepted 16 January 2013

Academic Editor: Alexander Tatarinov

Copyright (C) 2013 Kongzhai Li et al. This is an open access article distributed under the Creative Commons Attribution License, which permits unrestricted use, distribution, and reproduction in any medium, provided the original work is properly cited.

Conversion of methane to syngas using a chemical-looping concept is a novel method for syngas generation. This process is based on the transfer of gaseous oxygen source to fuel (e.g., methane) by means of a cycling process using solid oxides as oxygen carriers to avoid direct contact between fuel and gaseous oxygen. Syngas is produced through the gas-solid reaction between methane and solid oxides (oxygen carriers), and then the reduced oxygen carriers can be regenerated by a gaseous oxidant, such as air or water. The oxygen carrier is recycled between the two steps, and the syngas with a ratio of $\mathrm{H}_{2} / \mathrm{CO}=2.0$ can be obtained successively. Air is used instead of pure oxygen allowing considerable cost savings, and the separation of fuel from the gaseous oxidant avoids the risk of explosion and the dilution of product gas with nitrogen. The design and elaboration of suitable oxygen carriers is a key issue to optimize this method. As one of the most interesting oxygen storage materials, ceria-based and perovskite oxides were paid much attention for this process. This paper briefly introduced the recent research progresses on the oxygen carriers used in the chemical-looping selective oxidation of methane (CLSOM) to syngas.

\section{Introduction}

Methane, the principal constituent of natural gas and coalbed gas, is an excellent raw material for production of fuels and chemicals [1]. Conversion of methane to valueadded products can be achieved in two ways, either via syngas (a mixture of $\mathrm{CO}$ and $\mathrm{H}_{2}$ ) as an intermediate or directly into $\mathrm{C}_{2}$ and higher hydrocarbons. Since the direct catalytic conversion of methane is inefficient, almost all the commercial processes for large scale chemical utilization of methane such as Fischer-Tropsch synthesis, methanol, or dimethyl ether production involve syngas [2].

Syngas generation from methane can be achieved in three routes: water steam reforming (SMR), carbon dioxide reforming (CDR), and partial oxidation of methane (POM) [3]. The two reforming reactions are all highly endothermic and operated at high temperature and high pressure, termed as costly chemical processes. POM technology, by contrast, is a mildly exothermic route, which makes the process less energy and capital cost than the reforming routes. In addition, it also allows excellent syngas yield in compact reactors due to the fast reaction rate and product selectivity [3-5]. However, this technology requires additional safety measures to avoid the risk of explosion due to the premixing of $\mathrm{CH}_{4} / \mathrm{O}_{2}$ mixture and pure oxygen supply to avoid the dilution of syngas by nitrogen and the formation of $\mathrm{NO}_{x}$ [6], which partly offset its advantages in the saving of energy and capital cost. To avoid such problems, a chemical-looping concept was proposed to use in the POM technology.

\section{Chemical-Looping Concept}

The term "chemical looping" is a new concept for fuels conversion, which is based on the transfer of oxygen from gaseous oxygen source to the fuel by means of a cycling process using solid oxides as oxygen carriers to avoid direct 


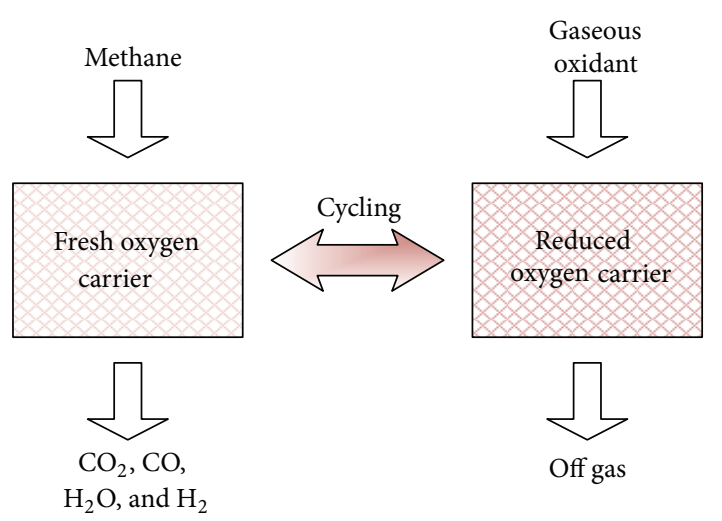

Figure 1: Schematic of chemical-looping concept for methane conversion.

contact between fuel and gaseous oxygen [7]. In the case of methane as fuel, the schematic of the chemical-looping process was shown in Figure 1. Lattice oxygen in oxygen carriers was used to oxidize methane, and then the reduced oxygen carriers can be reoxidized by gaseous oxidant to restore its initial state. Two interconnected reactors or fluidized-bed system are used in this technique to achieve the circulation of oxygen carrier between the oxidizing and reducing steps.

The first design using this concept was developed for power generation, which is known with the general term "chemical looping combustion" (CLC). For this process, the oxygen carrier can convert fuels to $\mathrm{H}_{2} \mathrm{O}$ and $\mathrm{CO}_{2}$, and the reduced oxygen carriers must be reoxidized by air. Because of the separation of fuels from air, this technology is identified as owning inherent advantages for $\mathrm{CO}_{2}$ separation with minimum energy losses [8]. Further designs of this concept were used in the syngas production from methane. After methane is oxidized to $\mathrm{CO}_{2}$ and $\mathrm{H}_{2} \mathrm{O}$ by oxygen carriers, the by-product gases $\left(\mathrm{CO}_{2}\right.$ and $\left.\mathrm{H}_{2} \mathrm{O}\right)$ were introduced into another reactor (reforming reactor) to reform with additional methane to produce syngas in the presence of a reforming catalyst (e.g., $\mathrm{Ni} / \mathrm{Al}_{2} \mathrm{O}_{3}$ ) $[9,10]$. Since the additional reforming process is a highly endothermic reaction needing large energy supply, this technology is less-than-ideal for syngas generation.

On the other hand, the direct generation of syngas by the reaction between oxygen carriers and methane is more acceptable, but this process needs an oxygen carrier owning ability to selectively oxidize methane. This vision was firstly realized over $\mathrm{CeO}_{2}$ oxygen carrier, and the authors also proposed that the reduced oxygen carrier can be reoxidized by $\mathrm{H}_{2} \mathrm{O}$ with obtaining $\mathrm{H}_{2}$ simultaneously $[11,12]$. In this case, the design and elaboration of suitable oxygen carriers with high activity, selectivity, and redox stability for methane selective oxidation is a key issue for this technology.

Comparing with the traditional POM process, the chemical-looping concept allows air instead of pure oxygen as oxygen source without the dilution of product gas with nitrogen, which brings about considerable cost saving. When using $\mathrm{H}_{2} \mathrm{O}$ as an oxidant (two-step SRM process), it gives the possibility of coproduction of pure hydrogen without separating equipments and syngas with a $\mathrm{H}_{2} / \mathrm{CO}$ ratio of 2.0 which is ideal for the major downstream processes such as methanol production or Fischer-Tropsch synthesis. The present paper would mainly discuss the progresses on the oxygen carriers for this technology.

\section{Oxygen Carriers for Chemical-Looping Selective Oxidation of Methane (CLSOM)}

Chemical-looping concept involves the use of a redox cycle process of chosen oxygen carriers to implement the selective oxidation of methane to syngas. The yield of syngas depends on the activity and selectivity of the oxygen in oxygen carriers. In this case, selection of the oxygen carrier, which relies on the understanding of reaction mechanism of methane selective oxidation in the absence of the gaseous oxygen, is considered as one of the most essential components of the CLSOM process.

For the CLC process, it is proposed that the oxygen carriers must own the following properties in chemistry [7, 8]: (i) sufficient oxygen storage and transport capacity; (ii) high reactivity in both reduction and oxidation cycles; (iii) ability to completely combust a fuel; (iv) ability of resistant to agglomeration and carbon deposition. This list also applies to the CLSOM oxygen carriers except the third one (iii), which should be changed to "ability to selectively oxidize a fuel."

Most of previous technical literatures on CLSOM focused on development of suitable oxygen carrier materials for methane selective oxidation. Ceria-based materials and perovskite-type oxides were paid the most attention due to their high lattice oxygen activity, excellent redox properties, and good thermal stability.

3.1. $\mathrm{CeO}_{2}$-Based Oxygen Carriers. The selective oxidation of methane to $\mathrm{CO}$ and $\mathrm{H}_{2}$ (syngas) by gas-solid reaction was firstly achieved over $\mathrm{CeO}_{2}$ oxygen carrier $[11,12]$. The reaction between methane and $\mathrm{CeO}_{2}$ may occur in four equations:

$$
\begin{gathered}
8 \mathrm{CeO}_{2}+\mathrm{CH}_{4} \longrightarrow 4 \mathrm{Ce}_{2} \mathrm{O}_{3}+\mathrm{CO}_{2}+\mathrm{H}_{2} \mathrm{O} \\
2 \mathrm{CeO}_{2}+\mathrm{CH}_{4} \longrightarrow \mathrm{Ce}_{2} \mathrm{O}_{3}+\mathrm{CO}+2 \mathrm{H}_{2} \\
\mathrm{CeO}_{2}+\mathrm{CH}_{4} \longrightarrow \mathrm{CeO}_{1.83}+\mathrm{CO}_{2}+\mathrm{H}_{2} \mathrm{O} \\
\mathrm{CeO}_{2}+\mathrm{CH}_{4} \longrightarrow \mathrm{CeO}_{1.83}+\mathrm{CO}+\mathrm{H}_{2} .
\end{gathered}
$$

The thermodynamic considerations of the reactions in (1)-(4) were shown in Figure 2. It is clear that the complete oxidation of methane to $\mathrm{CO}_{2}$ and $\mathrm{H}_{2} \mathrm{O}$ by $\mathrm{CeO}_{2}$ (reaction (1)) is thermodynamically unfeasible under $1000^{\circ} \mathrm{C}$, and the syngas generation through selective oxidation of methane by $\mathrm{CeO}_{2}$ is favorable with the reaction temperatures $\geq 700^{\circ} \mathrm{C}$. The experimental results supported the thermodynamic analysis [12]. It shows that syngas with $\mathrm{H}_{2} / \mathrm{CO}$ ratio of 2.0 was indeed produced via the gas-solid reaction between methane and $\mathrm{CeO}_{2}$ at $700^{\circ} \mathrm{C}$, and the reduction degree of $\mathrm{CeO}_{2}$ reached $21 \%$ with platinum as a catalyst, suggesting that almost all the $\mathrm{CeO}_{2}$ was reduced to $\mathrm{Ce}_{2} \mathrm{O}_{3}$. This indicates that the oxidation of methane over $\mathrm{CeO}_{2}$ may occur follow (2) in the presence of platinum. 


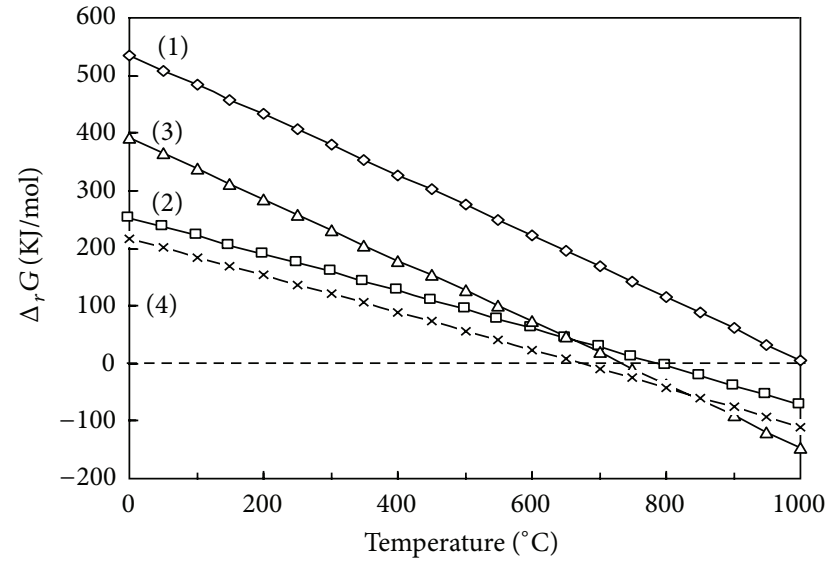

FIGURE 2: Thermodynamic calculations for the possible reactions between methane and $\mathrm{CeO}_{2}[14]$.

Fathi et al. [13] also investigated the reaction between methane and $\mathrm{CeO}_{2}$ with $\gamma-\mathrm{Al}_{2} \mathrm{O}_{3}$ as a support and $\mathrm{Pt}$ or $\mathrm{Rh}$ as a promoter. They observed that the selectivity to syngas depends on the reduction degree of $\mathrm{CeO}_{2}$. Numbers of $\mathrm{CO}_{2}$ and $\mathrm{H}_{2} \mathrm{O}$ were produce in the early stage of the reaction, and then the syngas selectivity increased quickly with the reduction degree of cerium oxide. Pt or Rh promoters could lower the temperature necessary to reduce the cerium oxide but also result in the formation of carbon deposition. Pantu et al. [6] found that the surface area of $\mathrm{Pt} / \mathrm{CeO}_{2}$ sample affects the formation rate of syngas: methane conversion slightly increased, and syngas selectivity slightly decreased with increasing surface area. This indicates that ether high or low surface area of oxygen carrier will reduce the yield of syngas. They also observed that there was no significant effect of Pt loading on the activity of $\mathrm{CeO}_{2}$ for methane oxidation, and the differences in metal dispersion on $\mathrm{CeO}_{2}$ are not substantial.

Wei et al. [14] investigated the effects of $\mathrm{CeO}_{2}$ loading on the reactivity of $\mathrm{CeO}_{2} / \gamma-\mathrm{Al}_{2} \mathrm{O}_{3}$ oxygen carrier for methane selective oxidation in the absence of platinum catalyst. The results showed that higher $\mathrm{CeO}_{2}$ loading will seriously decrease the selectivity of syngas. The other major innovation in this paper is the use of molten salt system as thermal carrier, which can avoid the agglomeration of circulating particles and improve the thermal efficiency of the whole reaction system.

It is generally accepted that the addition of $\mathrm{Zr}^{4+}$ could enhance the oxygen storage capacity by increasing the oxygen vacancies of ceria. Otsuka et al. [15] tested the reactivity of $\mathrm{Ce}_{1-x} \mathrm{Zr}_{x} \mathrm{O}_{2}$ for the direct conversion of methane to syngas by gas-solid reactions. The formation rates of $\mathrm{H}_{2}$ and $\mathrm{CO}$ were increased, and the activation energy was remarkably decreased due to the incorporation of $\mathrm{ZrO}_{2}$ into $\mathrm{CeO}_{2}$. The conversion of $\mathrm{CH}_{4}$ to $\mathrm{H}_{2}$ and $\mathrm{CO}$ could be achieved at a temperature as low as $500^{\circ} \mathrm{C}$ by using $\mathrm{Ce}_{0.8} \mathrm{Zr}_{0.2} \mathrm{O}_{2}$ in the presence of $\mathrm{Pt}$, which is $200^{\circ} \mathrm{C}$ lower than $\mathrm{CeO}_{2}$ sample. Pantu et al. [6] observed that addition of $\mathrm{ZrO}_{2}$ to $\mathrm{CeO}_{2}$ significantly increases the methane oxidation rate and the reducibility of the $\mathrm{CeO}_{2}$ but decreases the selectivity to $\mathrm{H}_{2}$ and CO. Wei et al. [16] also reported a similar observation on using $\mathrm{Ce}_{1-x} \mathrm{Zr}_{x} \mathrm{O}_{2}$ as oxygen carrier, but they found that the $\mathrm{ZrO}_{2}$-rich materials own better activity and stability.

Kang and Eyring $[17,18]$ investigated the activity of the $\mathrm{Ce}-\mathrm{Zr}-\mathrm{Tb}-\mathrm{O}$ system for methane oxidation and found that the oxygen transfer capacity and the oxygen storage capacity are equally important for syngas generation. The reactivity of ceria-zirconia oxides doped by $\mathrm{Pr}, \mathrm{Gd}$, or La for methane conversion was also investigated by $\mathrm{CH}_{4}$-TPR technology and pulse reduction experiments, and it is proved that Pr-doped sample showed good activity for syngas generation [19]. The reaction between methane and $\mathrm{Ce}-\mathrm{Zr}-\mathrm{Pr}-\mathrm{O}$ oxygen carrier with $\mathrm{Pt}$ as catalyst at high temperatures is controlled by the lattice oxygen diffusion, while the reactivity of weak bound surface oxygen determine the activity of the mixed oxides at the lowest temperature $\left(\sim 550^{\circ} \mathrm{C}\right)$.

Sadykov et al. [20] designed incorporating $\mathrm{Sm}^{3+}$ and $\mathrm{Bi}^{3+}$ cations into the ceria lattice to enhance the oxygen mobility while increasing the rate of methane dissociation by supporting $\mathrm{Pt}$, and the results were also compared with the $\mathrm{Pt} / \mathrm{Ce}-\mathrm{Zr}-\mathrm{La}-\mathrm{O}$ mixed oxides. It showed that only the CeSm-based oxide system is promising for methane selective oxidation by gas-solid reaction due to a high mobility and reactivity of the lattice oxygen, good selectivity for syngas generation, and high stability in redox cycles. The selective conversion of methane into syngas by lattice oxygen depends not only on the route of its primary activation (i.e., on supported Pt clusters) but on the features of activated fragments transformation on the support surface as well, provided the lattice oxygen mobility that is comparable.

Several reports showed that the oxidation activity and redox property of the ceria can be strongly enhanced by the addition of $\mathrm{Fe}^{3+}$ due to the formation of surface structural defects and Ce-Fe solid solution [21-25]. In addition, the modified iron oxides can also produce $\mathrm{CO}$ and $\mathrm{H}_{2}$ through reduction with methane in an appropriate condition $[26,27]$, and that the iron species can strongly enhance the adsorption of methane [28]. $\mathrm{Fe}_{2} \mathrm{O}_{3}$ is possibly the most common and one of the cheapest metal oxides available in nature, and $\mathrm{Fe}^{3+}$ are very suitable as an dopant to improve the performance of ceria $[29,30]$. Combination of $\mathrm{CeO}_{2}$ and $\mathrm{Fe}_{2} \mathrm{O}_{3}$ gives people very high expectation to obtain attractive oxygen carriers for methane selective oxidation. Given the above, the investigation on the possibility of using $\mathrm{CeO}_{2}-\mathrm{Fe}_{2} \mathrm{O}_{3}$ composite as oxygen carrier for methane selective oxidation attracted much attention [31-41]

It was reported that the $\mathrm{CeO}_{2}-\mathrm{Fe}_{2} \mathrm{O}_{3}$ mixed oxides own good activity, selectivity, and stability for syngas generation through gas-solid reactions, as shown in Figure 3, and the interaction between exposed $\mathrm{Fe}_{2} \mathrm{O}_{3}$ and $\mathrm{Ce}$-Fe solid solution in the oxygen carrier plays an important role on the syngas generation [36]. In addition, the dispersion of surface $\mathrm{Fe}_{2} \mathrm{O}_{3}$ and the formation of the Ce-Fe solid solution were enhanced by the redox treatment, which made the oxygen carrier very stable in the successive generation of syngas [36]. The selectivity of $\mathrm{Ce}-\mathrm{Fe}$ mixed oxides for syngas production is strongly affected by the specific surface area of oxygen carriers, and high surface area would result in abundant 


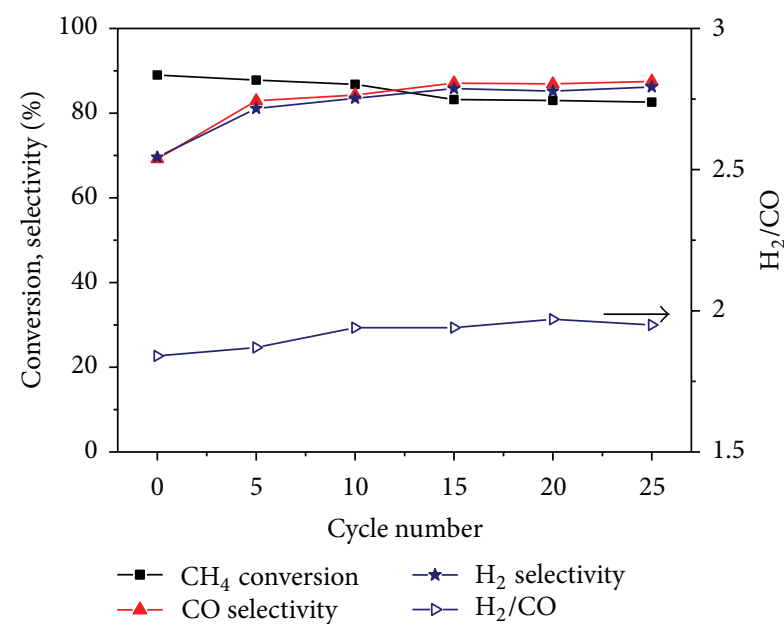

FIGURE 3: The effect of redox cycle number on the selective oxidation of methane using $\mathrm{Ce}_{0.7} \mathrm{Fe}_{0.3} \mathrm{O}_{2}$ oxygen carrier at $850^{\circ} \mathrm{C}$ [36].

surface adsorbed oxygen, favoring the complete oxidation of methane to carbon dioxide and water [42].

For the reaction process between methane and $\mathrm{Ce}-\mathrm{Fe}$ mixed oxides [36], methane was found to adsorb and activate on the reduced iron and cerium sites, and the subsequent oxidation of activated methane relied on the lattice oxygen mobility of the oxygen carrier. The dispersion of surface iron species and the consistence of oxygen vacancy in Ce-Fe mixed oxides in turn markedly affect the formation rate of syngas, and the strong interactions between dispersed Fe species and Ce-Fe solid solution have a distinct positive effect on the catalytic activity for methane selective oxidation.

Comparison of Ce-Zr and Ce-Fe mixed oxides demonstrated that the two samples showed similar activity for methane oxidation, but the $\mathrm{Ce}-\mathrm{Fe}$ sample revealed higher selectivity of syngas, as shown in Figure 4 [33]. Addition of $\mathrm{ZrO}_{2}$ into $\mathrm{CeO}_{2}-\mathrm{Fe}_{2} \mathrm{O}_{3}$ system could enhance the interaction between iron and cerium oxides via increasing the oxygen vacancy concentration and improving the dispersion of free $\mathrm{Fe}_{2} \mathrm{O}_{3}$, which improved the activity of Ce-Fe mixed oxides for methane selective oxidation. However, heavy loading of $\mathrm{ZrO}_{2}$ would lead to a phase segregation of $\mathrm{CeO}_{2}$ and $\mathrm{Fe}_{2} \mathrm{O}_{3}$ from the $\mathrm{Ce}-\mathrm{Fe}$ solid solution, resulting in a decrease in syngas selectivity [34].

The effect of supports $\left(\mathrm{Al}_{2} \mathrm{O}_{3}, \mathrm{SiO}_{2}\right.$, and $\left.\mathrm{MgO}\right)$ on the activity and selectivity of $\mathrm{Ce}-\mathrm{Fe}-\mathrm{Zr}$ mixed oxides for methane selective oxidation was also investigated [40]. $\mathrm{Al}_{2} \mathrm{O}_{3}$ support could result in the complete oxidation of methane, and $\mathrm{SiO}_{2}$ obvious reduced the reactivity of $\mathrm{Ce}-\mathrm{Fe}-\mathrm{Zr}$ mixed oxides. On the other hand, $\mathrm{MgO}$ support strongly enhanced the activity and selectivity of Ce-Fe-Zr oxygen carriers for syngas generation.

$\mathrm{Ce}-\mathrm{Cu}-\mathrm{O}, \mathrm{Ce}-\mathrm{Mn}-\mathrm{O}$, and $\mathrm{Ce}-\mathrm{Nb}-\mathrm{O}$ and $\mathrm{Ce}-\mathrm{Ni}-\mathrm{O}$ were also considered as an oxygen carrier for methane oxidation [38, 43-45]. Compared with the Ce-Fe mixed oxides, Ce$\mathrm{Cu}-\mathrm{O}$ and $\mathrm{Ce}-\mathrm{Mn}-\mathrm{O}$ oxygen carriers are more favorable to completely oxidize methane [38], and the $\mathrm{Ce}-\mathrm{Ni}-\mathrm{O}$ would result in the decomposition of methane when the Ni loading

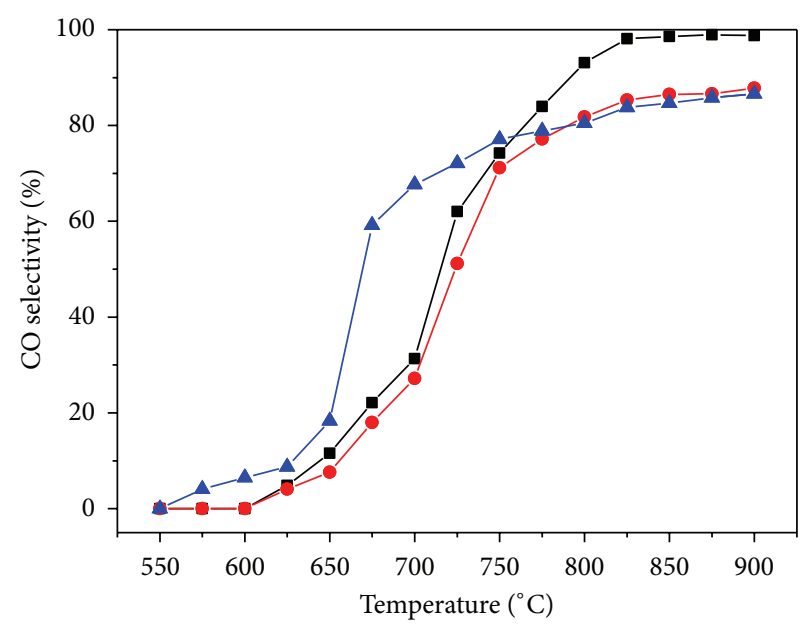

(a)

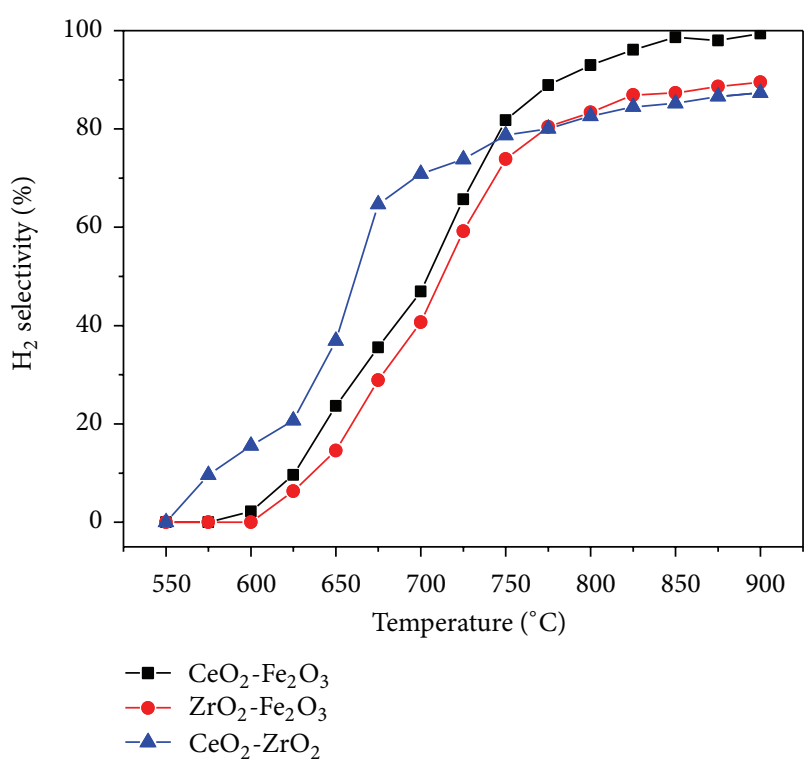

(b)

Figure 4: $\mathrm{CO}$ and $\mathrm{H}_{2}$ selectivity as a function of reaction temperature over $\mathrm{CeO}_{2}-\mathrm{Fe}_{2} \mathrm{O}_{3}, \mathrm{CeO}_{2}-\mathrm{ZrO}_{2}$, and $\mathrm{ZrO}_{2}-\mathrm{Fe}_{2} \mathrm{O}_{3}$ oxygen carriers [33].

is too high [44]. For Ce-Nb-O system, the further oxidation of hydrogen to water was observed, and the $\mathrm{CO}$ and $\mathrm{H}_{2} \mathrm{O}$ were the main production [45]. For all ceria-based oxygen carriers, the reoxidation process by air is very easy to accomplish.

3.2. Perovskite Oxygen Carriers. Perovskite oxides with an $\mathrm{ABO}_{3}$-type crystal structure usually exhibit excellent redox properties, high oxygen mobility, and thermal stability, which can be used in many reactions related to a redox process, such as catalytic purification of automotive exhaust and solid oxide fuel cell (SOFC) [46-50]. As a famous perovskite oxides, $\mathrm{LaFeO}_{3}$ was firstly chosen to selectively oxidize methane by Dai et al. [51, 52], and its performance was compared with $\mathrm{NdFeO}_{3}$ and $\mathrm{EuFeO}_{3}$. The oxygen storage and transport 
ability of $\mathrm{AFeO}_{3}(\mathrm{~A}=\mathrm{La}, \mathrm{Nd}$, and $\mathrm{Eu})$ is related to its $\mathrm{Fe}-$ $\mathrm{O}$ bond distance and shorter distance given lower activity of oxygen. The reaction rate between methane $\mathrm{AFeO}_{3}$ strongly depends on the reaction temperature, and high-temperature $\left(>800^{\circ} \mathrm{C}\right)$ is necessary for obtaining a high syngas yield. The $\mathrm{LaFeO}_{3}$ oxide exhibits the best performance among these tested $\mathrm{AFeO}_{3}$ oxides $(\mathrm{A}=\mathrm{La}, \mathrm{Nd}$, and $\mathrm{Eu})$ for syngas production, and it also maintains high catalytic activity and structural stability in the redox experiment between methane and air at $900^{\circ} \mathrm{C}$. It was also observed that the reduction of $\mathrm{LaFeO}_{3}$ by methane was performed through a reduction of $\mathrm{Fe}^{3+}$ to $\mathrm{Fe}^{2+}$, and further reduction is very difficult [53]. They also investigated the redox property of $\mathrm{LaFeO}_{3}$ for successive generation of syngas in a circulating-fluidized bed (CFB) reactor [54]. It showed that methane could be oxidized to syngas by lattice oxygen with high selectivity, and the depleted oxygen species could be regenerated in a CFB condition. The methane conversion remains at $60 \%-$ $70 \%$ with the CO selectivity of ca. $96 \%$ during the 30 redox cycles. However, this paper did not involve the mechanical performance of the oxygen carriers in the redox process, and it is proposed that the attrition resistance for CFB process should be paid much attention.

$\mathrm{Li}$ et al. $[55,56]$ added $\mathrm{Sr}$ into the $\mathrm{LaFeO}_{3}$ system to partially substitute the sites of $\mathrm{La}$ and investigated that performance of the $\mathrm{La}_{0.8} \mathrm{Sr}_{0.2} \mathrm{FeO}_{3}$ oxide for methane selective oxidation. They proposed that there are two kinds of oxygen species on the oxide: (i) the active oxygen species (weakly bound oxygen species) which are responsible for complete oxidation of methane and (ii) the weaker oxygen species (strongly bound oxygen species) which are responsible for partial oxidation of methane to syngas. This is similar with the observation by Greish et al. [57]. Methane reacts firstly with the active oxygen species to form $\mathrm{CO}_{2}$ and $\mathrm{H}_{2} \mathrm{O}$, and then the weaker oxygen species can oxidize methane to $\mathrm{CO}$ and $\mathrm{H}_{2}$ with high selectivity.

On the other hand, substituting $\mathrm{La}$ for $\mathrm{Sr}$ was found to increase the oxygen capacity of these materials but reduce the selectivity to syngas and the reactivity with $\mathrm{CH}_{4}$ [58]. Addition of $\mathrm{Cr}, \mathrm{Ni}$, and $\mathrm{Cu}$ into the $\mathrm{La}-\mathrm{Sr}-\mathrm{Fe}-\mathrm{O}$ perovskite system to partially replace the Fe sites could improve the reactivity for methane conversion [59], while incorporation of Co ions into $\mathrm{La}-\mathrm{Sr}-\mathrm{Fe}-\mathrm{O}$ mixed oxides could enhance the activity of this material for methane combustion [58] and reduce the stability under redox testing [60]. The $\mathrm{La}_{0.7} \mathrm{Sr}_{0.3} \mathrm{Cr}_{0.1} \mathrm{Fe}_{0.9} \mathrm{O}_{3}$ with physically mixed $\mathrm{NiO}$ as a catalyst showed good activity and stability in the redox testing [59]. The improvement on the syngas production and stability of material was also observed over the $\mathrm{NiO} / \mathrm{La}_{1-x} \mathrm{Sr}_{x} \mathrm{FeO}_{3}$ system due to the presence of exposed $\mathrm{NiO}$ particles, but the presence of $\mathrm{NiO}$ also improved the catalytic activity for methane decomposition, resulting in the formation of carbon deposition [61].

$\mathrm{La}_{1-x} \mathrm{Sr}_{x} \mathrm{MO}_{3}(\mathrm{M}=\mathrm{Mn}, \mathrm{Ni})$ and $\mathrm{LaMnO}_{3-\alpha} \mathrm{F}_{\beta}$ perovskite oxides were also investigated as oxygen carriers for methane oxidation [62]. It is proposed that the reactivity and selectivity of lattice oxygen depend on (i) B-site element, (ii) degree of substitution of La with $\mathrm{Sr}$, and (iii) fluorination of the perovskite oxide. The $\mathrm{La}_{1-x} \mathrm{Sr}_{x} \mathrm{MO}_{3}$ with relatively low degree of Sr-substitution and the fluorinated $\mathrm{LaMnO}_{3-\alpha} \mathrm{F}$ are suitable oxygen carriers for syngas generation. The high substitution degree of $\mathrm{La}$ by $\mathrm{Sr}$ increases the reactivity of lattice oxygen but decreases the selectivity to syngas. Evdou et al. [61] observed that the reduction degree of $\mathrm{La}_{1-x} \mathrm{Sr}_{x} \mathrm{MO}_{3}$ oxides by methane relies on the $\mathrm{Sr}$ content and the reaction temperature.

$\mathrm{BaTi}_{1-x} \mathrm{In}_{x} \mathrm{O}_{3}$ perovskite oxides with nickel as a catalyst were also investigated for methane oxidation in the absence of gas phase oxygen [63]. Based on the temperatureprogrammed surface reaction of methane (TPSR- $\mathrm{CH}_{4}$ ) and pulses reaction results, they found that the reducibility of $\mathrm{B}$ cation $\left(\mathrm{ABO}_{3}\right)$ and the anionic conductivity of the material strongly influence the activity and selectivity of $\mathrm{BaTi}_{1-x} \mathrm{In}_{x} \mathrm{O}_{3}$ oxygen carriers. It is also observed that $\mathrm{Ni} / \mathrm{BaTi}_{0.3} \mathrm{In}_{0.7} \mathrm{O}_{3}$ oxygen carrier was more stable than $\mathrm{Ni} / \mathrm{BaTiO}_{3}$ due to the existence of Ni-In alloys which is relatively inert for catalyzing the cracking reaction.

3.3. Other Oxygen Carriers. $\mathrm{Fe}_{2} \mathrm{O}_{3}$ as oxygen carrier was proved to own the ability for methane combustion $[7,8]$, but addition of other suitable oxides can modify the selectivity of its lattice oxygen for selective oxidation of methane to syngas. $\mathrm{Fe}_{2} \mathrm{O}_{3}-\mathrm{Rh}_{2} \mathrm{O}_{3} / \mathrm{Y}_{2} \mathrm{O}_{3}$ and $\mathrm{Fe}_{2} \mathrm{O}_{3}-\mathrm{Cr}_{2} \mathrm{O}_{3}-\mathrm{MgO}$ oxides were found to be active to produce syngas with a moderate methane conversion and selectivity [64]. It is also proved that combining $\mathrm{CuO}$ and $\mathrm{Fe}_{2} \mathrm{O}_{3}$ to form a Cu-ferrite could obtain a suitable oxygen carrier for methane selective oxidation. Cha et al. $[65,66]$ investigated the reactivity of $\mathrm{Cu}_{x} \mathrm{Fe}_{3-x} \mathrm{O}_{4} / \mathrm{Ce}$ $\mathrm{ZrO}_{2}(x<1)$ for methane selective oxidation, and the results showed that the $\mathrm{Cu}$-ferrite suppressed carbon deposition and promoted the reactivity with methane to produce syngas. On the other hand, since the lattice oxygen from $\mathrm{Fe}_{2} \mathrm{O}_{3}$ to $\mathrm{Fe}_{3} \mathrm{O}_{4}$ can completely oxidize methane to $\mathrm{CO}_{2}$ and $\mathrm{H}_{2} \mathrm{O}$, the redox of $\mathrm{FeO} / \mathrm{Fe}_{3} \mathrm{O}_{4}$ was proposed to convert methane to syngas by a chemical looping step [67].

NiO-based materials were also used for the methane selective oxidation, but significant amount of $\mathrm{CO}_{2}$ and $\mathrm{H}_{2} \mathrm{O}$ was observed in the products over $\mathrm{NiO}, \mathrm{NiO} / \gamma-\mathrm{Al}_{2} \mathrm{O}_{3}$, $\mathrm{NiO} / \alpha-\mathrm{Al}_{2} \mathrm{O}_{3}$, and $\mathrm{NiO} / \mathrm{Mg}-\mathrm{ZrO}_{2}$ oxygen carriers [68-73]. During the reaction between methane and $\mathrm{NiO}$-based oxides, the syngas yield depends on the oxidation degree of the oxygen carriers: highly oxidized oxide particles resulted in the formation of $\mathrm{CO}_{2}$ and $\mathrm{H}_{2} \mathrm{O}$, while reduced particles could produce $\mathrm{CO}$ and $\mathrm{H}_{2}[70,74]$. Addition of $\mathrm{Cr}_{2} \mathrm{O}_{3}$ into $\mathrm{NiO}$ $\mathrm{MgO}$ system could change reactivity of the lattice oxygen in the materials, and the fully oxidized $\mathrm{NiO}-\mathrm{Cr}_{2} \mathrm{O}_{3}-\mathrm{MgO}$ produced $\mathrm{H}_{2}$ and $\mathrm{CO}$ with high selectivity during the reaction with $\mathrm{CH}_{4}[64,75]$. The appearance of $\mathrm{NiAl}_{2} \mathrm{O}_{4}$ also could reduce the activity of oxygen in the material and promote the formation of $\mathrm{H}_{2}$ and $\mathrm{CO}$ [76].

Based on the previous discussions, $\mathrm{CeO}_{2}$-based oxygen carrier could convert methane into syngas at relatively low temperatures $\left(\mathrm{ca} .700^{\circ} \mathrm{C}\right.$ ) in the presence of Pt promoter, but the redox stability of the oxygen carriers needs to be improved. The perovskite-type oxygen carriers own high selectivity and redox stability for syngas generation, but they are only active at high temperatures $\left(\mathrm{ca} .850^{\circ} \mathrm{C}\right)$. For the $\mathrm{Fe}_{2} \mathrm{O}_{3}$ - and NiO-based oxygen carriers, a large number of $\mathrm{CO}_{2}$ and $\mathrm{H}_{2} \mathrm{O}$ were produced during the gas-solid reaction 
between oxygen carrier and methane. Although addition of suitable promoters could improve the selectivity of oxygen carriers for syngas generation, but it also reduced the reactivity for methane conversion. Among the different oxygen carriers, perovskite-type oxygen carriers are more competitive for the CLSOM process, if the activity could be enhanced by the structure modifications. On the other hand, the use of the various combinations of catalysts (e.g., combinations of perovskite-type or $\mathrm{CeO}_{2}-\mathrm{ZrO}_{2}$ oxygen carriers with $\mathrm{Ni}$ or Fe species) may also achieve the greater efficiency for syngas generation.

\section{Conclusions}

Chemical-looping selective oxidation of methane (CLSOM) is a promising, energy-efficient, and low-cost route for syngas generation. However, at the present time, this technology is not fully established for large-scale implementation, and valuable researches need to be developed to address the important issues of this technology. Nowadays, numbers of works were performed on this technology, and most of previous technical literatures had been focused on the development of suitable oxygen carrier materials. After reviewing such references, it is found that a suitable oxygen carrier should own abundant active sites for methane activation, high oxygen storage capacity, and good oxygen mobility. This finding gives useful references for the further developing highly efficient oxygen carriers.

Due to the two-step redox process, the chemical engineering of whole process is actually a key factor for success in practical application, and the specific selected reactor design is very critical. The mechanical performance of the oxygen carriers should be paid much attention when a fluidized bed reactor is used. In addition, since the reaction between methane and oxygen carriers is endothermic, while the reoxidation of reduced oxygen carriers is an exothermic reaction, the energy efficiency of the whole process strongly depends on the transfer of the heat from the exothermic reaction to the endothermic reaction. This issue is also very important for the practical application of this technology.

\section{Acknowledgments}

This paper was supported by the National Nature Science Foundation of China (Project nos. 51004060 and 51174105), National Excellent Doctoral Dissertation Development Foundation of Kunming University of Science and Technology, Natural Science Foundation of Yunnan Province (no. 2010ZC018), and a school-enterprise cooperation project from Jinchuan Corporation (no. Jinchuan 201115).

\section{References}

[1] J. R. Rostrup-Nielsen, "Fuels and energy for the future: the role of catalysis," Catalysis Reviews, vol. 46, no. 3-4, pp. 247-270, 2004.

[2] A. Holmen, "Direct conversion of methane to fuels and chemicals," Catalysis Today, vol. 142, no. 1-2, pp. 2-8, 2009.

[3] B. C. Enger, R. Lødeng, and A. Holmen, "A review of catalytic partial oxidation of methane to synthesis gas with emphasis on reaction mechanisms over transition metal catalysts," Applied Catalysis A, vol. 346, no. 1-2, pp. 1-27, 2008.

[4] P. M. Torniainen, X. Chu, and L. D. Schmidt, "Comparison of monolith-supported metals for the direct oxidation of methane to syngas," Journal of Catalysis, vol. 146, no. 1, pp. 1-10, 1994.

[5] L. Bobrova, N. Vernikovskaya, and V. Sadykov, "Conversion of hydrocarbon fuels to syngas in a short contact time catalytic reactor," Catalysis Today, vol. 144, no. 3-4, pp. 185-200, 2009.

[6] P. Pantu, K. Kim, and G. R. Gavalas, "Methane partial oxidation on $\mathrm{Pt} / \mathrm{CeO}_{2}-\mathrm{ZrO}_{2}$ in the absence of gaseous oxygen," Applied Catalysis A, vol. 193, no. 1-2, pp. 203-214, 2000.

[7] J. Adanez, A. Abad, F. Garcia-Labiano, P. Gayan, and L. F. de Diego, "Progress in chemical-looping combustion and reforming technologies," Progress in Energy and Combustion Science, vol. 38 , no. 2, pp. 215-282, 2012.

[8] M. M. Hossain and H. I. de Lasa, "Chemical-looping combustion (CLC) for inherent $\mathrm{CO}_{2}$ separations-a review," Chemical Engineering Science, vol. 63, no. 18, pp. 4433-4451, 2008.

[9] F. vanlooij, J. C. van Giezen, E. R. Stobbe, and J. W. Geus, "Mechanism of the partial oxidation of methane to synthesis gas on a silica-supported nickel catalyst," Catalysis Today, vol. 21, no. 2-3, pp. 495-503, 1994.

[10] E. R. Stobbe, B. A. De Boer, and J. W. Geus, "The reduction and oxidation behaviour of manganese oxides," Catalysis Today, vol. 47, no. 1-4, pp. 161-167, 1999.

[11] K. Otsuka, T. Ushiyama, and I. Yamanaka, "Partial oxidation of methane using the redox of cerium oxide," Chemistry Letters, pp. 1517-1520, 1993.

[12] K. Otsuka, Y. Wang, E. Sunada, and I. Yamanaka, "Direct partial oxidation of methane to synthesis gas by cerium oxide," Journal of Catalysis, vol. 175, no. 2, pp. 152-160, 1998.

[13] M. Fathi, E. Bjorgum, T. Viig, and O. A. Rokstad, "Partial oxidation of methane to synthesis gas: elimination of gas phase oxygen," Catalysis Today, vol. 63, no. 2-4, pp. 489-497, 2000.

[14] Y. Wei, H. Wang, F. He, X. Ao, and C. Zhang, " $\mathrm{CeO}_{2}$ as the oxygen carrier for partial oxidation of methane to synthesis gas in molten salts: thermodynamic analysis and experimental investigation," Journal of Natural Gas Chemistry, vol. 16, no. 1, pp. 6-11, 2007.

[15] K. Otsuka, Y. Wang, and M. Nakamura, "Direct conversion of methane to synthesis gas through gas-solid reaction using $\mathrm{CeO}_{2}-\mathrm{ZrO}_{2}$ solid solution at moderate temperature," Applied Catalysis A, vol. 183, no. 2, pp. 317-324, 1999.

[16] Y. G. Wei, H. Wang, K. Z. Li, M. C. Liu, and X. Q. Ao, "Preparation and performance of $\mathrm{Ce} / \mathrm{Zr}$ mixed oxides for direct conversion of methane to syngas," Journal of Rare Earths, vol. 25, pp. 110-114, 2007.

[17] Z. C. Kang and L. Eyring, "Hydrogen production from methane and water by lattice oxygen transfer with $\mathrm{Ce}_{0.70} \mathrm{Zr}_{0.25} \mathrm{~Tb}_{0.05} \mathrm{O}_{2-x}$," Journal of Alloys and Compounds, vol. 323-324, pp. 97-101, 2001.

[18] Z. C. Kang and L. Eyring, "Lattice oxygen transfer in fluoritetype oxides containing Ce, Pr, and/or Tb," Journal of Solid State Chemistry, vol. 155, no. 1, pp. 129-137, 2000.

[19] V. A. Sadykov, N. N. Sazonova, A. S. Bobin et al., "Partial oxidation of methane on Pt-supported lanthanide doped ceriazirconia oxides: effect of the surface/lattice oxygen mobility on catalytic performance," Catalysis Today, vol. 169, no. 1, pp. 125137, 2011.

[20] V. A. Sadykov, T. G. Kuznetsova, G. M. Alikina et al., "Ceriabased fluorite-like oxide solid solutions as catalysts of methane 
selective oxidation into syngas by the lattice oxygen: synthesis, characterization and performance," Catalysis Today, vol. 93-95, pp. 45-53, 2004.

[21] C. Liu, L. Luo, and X. Lu, "Preparation of mesoporous $\mathrm{Ce}_{1-x}$ $\mathrm{Fe}_{x} \mathrm{O}_{2}$ mixed oxides and their catalytic properties in methane combustion," Kinetics and Catalysis, vol. 49, no. 5, pp. 676-681, 2008.

[22] J. Y. Luo, M. Meng, J. S. Yao et al., "One-step synthesis of nanostructured Pd-doped mixed oxides $\mathrm{MO}_{x}-\mathrm{CeO}_{2}(\mathrm{M}=\mathrm{Mn}, \mathrm{Fe}$, $\mathrm{Co}, \mathrm{Ni}, \mathrm{Cu}$ ) for efficient $\mathrm{CO}$ and $\mathrm{C}_{3} \mathrm{H}_{8}$ total oxidation," Applied Catalysis B, vol. 87, no. 1-2, pp. 92-103, 2009.

[23] H. Lv, H. Y. Tu, B. Y. Zhao, Y. J. Wu, and K. A. Hu, "Synthesis and electrochemical behavior of $\mathrm{Ce}_{1-x} \mathrm{Fe}_{x} \mathrm{O}_{2-\delta}$ as a possible SOFC anode materials," Solid State Ionics, vol. 177, no. 39-40, pp. 3467$3472,2007$.

[24] H. Lv, D. J. Yang, X. M. Pan et al., "Performance of Ce/Fe oxide anodes for SOFC operating on methane fuel," Materials Research Bulletin, vol. 44, no. 6, pp. 1244-1248, 2009.

[25] C. Liang, Z. Ma, H. Lin et al., "Template preparation of nanoscale $\mathrm{Ce}_{x} \mathrm{Fe}_{1-x} \mathrm{O}_{2}$ solid solutions and their catalytic properties for ethanol steam reforming," Journal of Materials Chemistry, vol. 19, no. 10, pp. 1417-1424, 2009.

[26] S. Takenaka, M. Serizawa, and K. Otsuka, "Formation of filamentous carbons over supported Fe catalysts through methane decomposition," Journal of Catalysis, vol. 222, no. 2, pp. 520-531, 2004.

[27] O. Nakayama, N. O. Ikenaga, T. Miyake, E. Yagasaki, and T. Suzuki, "Partial oxidation of $\mathrm{CH}_{4}$ with air to produce pure hydrogen and syngas," Catalysis Today, vol. 138, no. 3-4, pp. 141146, 2008.

[28] S. Fukuda, T. Hino, and T. Yamashina, "Desorption processes of hydrogen and methane from clean and metal-deposited graphite irradiated by hydrogen ions," Journal of Nuclear Materials, vol. 162-164, no. C, pp. 997-1003, 1989.

[29] G. Li, R. L. Smith, and H. Inomata, "Synthesis of nanoscale $\mathrm{Ce}_{1-x} \mathrm{Fe}_{x} \mathrm{O}_{2}$ solid solutions via a low-temperature approach," Journal of the American Chemical Society, vol. 123, no. 44, pp. 11091-11092, 2001.

[30] F. J. Pérez-Alonso, M. L. Granados, M. Ojeda et al., "Chemical structures of coprecipitated Fe-Ce mixed oxides," Chemistry of Materials, vol. 17, no. 9, pp. 2329-2339, 2005.

[31] K. Li, H. Wang, Y. Wei, and M. Liu, "Catalytic performance of cerium iron complex oxides for partial oxidation of methane to synthesis gas," Journal of Rare Earths, vol. 26, no. 5, pp. 705-710, 2008.

[32] K. Li, H. Wang, Y. Wei, and M. Liu, "Preparation and characterization of $\mathrm{Ce}_{1-x} \mathrm{Fe}_{x} \mathrm{O}_{2}$ complex oxides and its catalytic activity for methane selective oxidation," Journal of Rare Earths, vol. 26, no. 2, pp. 245-249, 2008.

[33] K. Li, H. Wang, Y. Wei, and D. Yan, "Direct conversion of methane to synthesis gas using lattice oxygen of $\mathrm{CeO}_{2}-\mathrm{Fe}_{2} \mathrm{O}_{3}$ complex oxides," Chemical Engineering Journal, vol. 156, no. 3, pp. 512-518, 2010.

[34] K. Z. Li, H. Wang, Y. G. Wei, and D. X. Yan, "Partial oxidation of methane to syngas with air by lattice oxygen transfer over $\mathrm{ZrO}_{2}$ modified Ce-Fe mixed oxides," Chemical Engineering Journal, vol. 173, pp. 574-582, 2011.

[35] Y. Wei, H. Wang, and K. Li, "Ce-Fe-O mixed oxide as oxygen carrier for the direct partial oxidation of methane to syngas," Journal of Rare Earths, vol. 28, no. 4, pp. 560-565, 2010.
[36] K. Li, H. Wang, Y. Wei, and D. Yan, "Syngas production from methane and air via a redox process using $\mathrm{Ce}-\mathrm{Fe}$ mixed oxides as oxygen carriers," Applied Catalysis B, vol. 97, no. 3-4, pp. 361$372,2010$.

[37] K. Li, H. Wang, Y. Wei, X. Ao, and M. Liu, "Partial oxidation of methane to synthesis gas using lattice oxygen," Progress in Chemistry, vol. 20, no. 9, pp. 1306-1314, 2008.

[38] F. He, Y. Wei, H. Li, and H. Wang, "Synthesis gas generation by Chemical-looping reforming using Ce-based oxygen carriers modified with $\mathrm{Fe}, \mathrm{Cu}$, and $\mathrm{Mn}$ oxides," Energy and Fuels, vol. 23, no. 4, pp. 2095-2102, 2009.

[39] X. Zhu, H. Wang, Y. Wei, K. Li, and X. Cheng, "Hydrogen and syngas production from two-step steam reforming of methane over $\mathrm{CeO}_{2}-\mathrm{Fe}_{2} \mathrm{O}_{3}$ oxygen carrier," Journal of Rare Earths, vol. 28, no. 6, pp. 907-913, 2010.

[40] X. Cheng, H. Wang, Y. Wei, K. Li, and X. Zhu, "Preparation and characterization of $\mathrm{Ce}-\mathrm{Fe}-\mathrm{Zr}-\mathrm{O}(\mathrm{x}) / \mathrm{MgO}$ complex oxides for selective oxidation of methane to synthesize gas," Journal of Rare Earths, vol. 28, no. 1, pp. 316-321, 2010.

[41] H. Kaneko, H. Ishihara, S. Taku, Y. Naganuma, N. Hasegawa, and Y. Tamaura, "Cerium ion redox system in $\mathrm{CeO}_{2-x} \mathrm{Fe}_{2} \mathrm{O}_{3}$ solid solution at high temperatures $(1,273-1,673 \mathrm{~K})$ in the twostep water-splitting reaction for solar $\mathrm{H}_{2}$ generation," Journal of Materials Science, vol. 43, no. 9, pp. 3153-3161, 2008.

[42] K. Li, H. Wang, Y. Wei, and D. Yan, “Transformation of methane into synthesis gas using the redox property of Ce-Fe mixed oxides: effect of calcination temperature," International Journal of Hydrogen Energy, vol. 36, no. 5, pp. 3471-3482, 2011.

[43] K. Z. Li, H. Wang, Y. G. Wei, and M. C. Liu, "Partial oxidation of methane to syngas using lattice oxygen from ceria-based complex oxides oxygen carriers," Journal of Fuel Chemistry and Technology, vol. 36, no. 1, pp. 83-88, 2008.

[44] Y. Wei, H. Wang, K. Li, X. Zhu, and Y. Du, "Preparation and characterization of $\mathrm{Ce}_{1-x} \mathrm{NixO}_{2}$ as oxygen carrier for selective oxidation methane to syngas in absence of gaseous oxygen," Journal of Rare Earths, vol. 28, no. 1, pp. 357-361, 2010.

[45] A. A. Yaremchenko, V. V. Kharton, S. A. Veniaminov, V. D. Belyaev, V. A. Sobyanin, and F. M. B. Marques, "Methane oxidation by lattice oxygen of $\mathrm{CeNbO}_{4+\delta}$," Catalysis Communications, vol. 8, no. 3, pp. 335-339, 2007.

[46] U. Balachandran, J. T. Dusek, R. L. Mieville et al., "Dense ceramic membranes for partial oxidation of methane to syngas," Applied Catalysis A, vol. 133, no. 1, pp. 19-29, 1995.

[47] V. R. Choudhary, S. Banerjee, and B. S. Uphade, "Activation by hydrothermal treatment of low surface area ABO3-type perovskite oxide catalysts," Applied Catalysis A, vol. 197, no. 2, pp. L183-L186, 2000.

[48] N. E. Trofimenko and H. Ullmann, "Oxygen stoichiometry and mixed ionic-electronic conductivity of $\mathrm{Sr}_{1-a} \mathrm{Ce}_{a} \mathrm{Fe}_{1-b} \mathrm{Co}_{b} \mathrm{O}_{3-x}$ perovskite-type oxides," Journal of the European Ceramic Society, vol. 20, no. 9, pp. 1241-1250, 2000.

[49] M. van den Bossche and S. McIntosh, "The rate and selectivity of methane oxidation over $\mathrm{La}_{0.75} \mathrm{Sr}_{0.25} \mathrm{Cr}_{x} \mathrm{Mn}_{1-x} \mathrm{O}_{3-\delta}$ as a function of lattice oxygen stoichiometry under solid oxide fuel cell anode conditions," Journal of Catalysis, vol. 255, no. 2, pp. 313-323, 2008.

[50] A. Khanfekr, K. Arzani, A. Nemati, and M. Hosseini, "Production of perovskite catalysts on ceramic monoliths with nanoparticles for dual fuel system automobiles," International Journal of Environmental Science and Technology, vol. 6, no. 1, pp. 105-112, 2009. 
[51] X. P. Dai, R. J. Li, C. C. Yu, and Z. P. Hao, "Unsteady-state direct partial oxidation of methane to synthesis gas in a fixed-bed reactor using $\mathrm{AFeO}_{3}(\mathrm{~A}=\mathrm{La}, \mathrm{Nd}, \mathrm{Eu})$ perovskite-type oxides as oxygen storage," Journal of Physical Chemistry B, vol. 110, no. 45, pp. 22525-22531, 2006.

[52] X. P. Dai and C. C. Yu, "Nano-perovskite-based $\left(\mathrm{LaMO}_{3}\right)$ oxygen carrier for syngas generation by chemical-looping reforming of methane," Chinese Journal of Catalysis, vol. 32, pp. 1411$1417,2011$.

[53] O. Mihai, D. Chen, and A. Holmen, "Catalytic consequence of oxygen of lanthanum ferrite perovskite in chemical looping reforming of methane," Industrial and Engineering Chemistry Research, vol. 50, no. 5, pp. 2613-2621, 2011.

[54] X. Dai, C. Yu, R. Li, Q. Wu, and Z. Hao, "Synthesis gas production using oxygen storage materials as oxygen carrier over circulating fluidized bed," Journal of Rare Earths, vol. 26, no. 1, pp. 76-80, 2008.

[55] R. Li, C. Yu, X. Dai, and S. Shen, "Selective oxidation of methane to synthesis gas using lattice oxygen from perovskite $\mathrm{La}_{0.8} \mathrm{Sr}_{0.2} \mathrm{FeO}_{3}$ catalyst," Chinese Journal of Catalysis, vol. 23, no. 6, pp. 549-554, 2002.

[56] R. J. Li, C. C. Yu, W. J. Ji, and S. K. Shen, "Methane oxidation to synthesis gas using lattice oxygen in $\mathrm{La}_{1-x} \mathrm{SrxFeO}_{3}$ perovskite oxides instead of molecular oxygen," Studies in Surface Science and Catalysis, vol. 147, pp. 199-204, 2004.

[57] A. A. Greish, L. M. Glukhov, E. D. Finashina et al., "Oxidative coupling of methane in the redox cyclic mode over the catalysts on the basis of $\mathrm{CeO}_{2}$ and $\mathrm{La}_{2} \mathrm{O}_{2}$," Mendeleev Communications, vol. 20, no. 1, pp. 28-30, 2010.

[58] M. Rydén, A. Lyngfelt, T. Mattisson, D. Chen, A. Holmen, and E. Bjørgum, "Novel oxygen-carrier materials for chemicallooping combustion and chemical-looping reforming; $\mathrm{LaxSr}_{1-x} \mathrm{Fe}_{y} \mathrm{Co}_{1-y} \mathrm{O}_{3-\delta}$ perovskites and mixed-metal oxides of $\mathrm{NiO}, \mathrm{Fe}_{2} \mathrm{O}_{3}$ and $\mathrm{Mn}_{3} \mathrm{O}_{4}$," International Journal of Greenhouse Gas Control, vol. 2, no. 1, pp. 21-36, 2008.

[59] L. Nalbandian, A. Evdou, and V. Zaspalis, " $\mathrm{La}_{1-x} \mathrm{Sr}_{x} \mathrm{M}_{y} \mathrm{Fe}_{1-y} \mathrm{O}_{3-\delta}$ perovskites as oxygen-carrier materials for chemical-looping reforming," International Journal of Hydrogen Energy, vol. 36, no. 11, pp. 6657-6670, 2011.

[60] A. Murugan, A. Thursfield, and I. S. Metcalfe, "A chemical looping process for hydrogen production using iron-containing perovskites," Energy \& Environmental Science, vol. 4, pp. 46394649, 2011.

[61] A. Evdou, V. Zaspalis, and L. Nalbandian, " $\mathrm{La}_{1-x} \mathrm{Sr}_{x} \mathrm{FeO}_{3-\delta}$ perovskites as redox materials for application in a membrane reactor for simultaneous production of pure hydrogen and synthesis gas," Fuel, vol. 89, no. 6, pp. 1265-1273, 2010.

[62] H. J. Wei, Y. Cao, W. J. Ji, and C. T. Au, "Lattice oxygen of $\mathrm{La}_{1-x} \mathrm{Sr}_{x} \mathrm{MO}_{3}(\mathrm{M}=\mathrm{Mn}, \mathrm{Ni})$ and $\mathrm{LaMnO}_{3-\alpha} \mathrm{F}_{\beta}$ perovskite oxides for the partial oxidation of methane to synthesis gas," Catalysis Communications, vol. 9, no. 15, pp. 2509-2514, 2008.

[63] V. García, M. T. Caldes, O. Joubert, E. Gautron, F. Mondragón, and A. Moreno, "Methane oxidation by lattice oxygen of $\mathrm{Ni} /$ $\mathrm{BaTi}_{1-x} \operatorname{In}_{x} \mathrm{O}_{3-\delta}$ catalysts," Catalysis Today, vol. 157, no. 1-4, pp. 177-182, 2010.

[64] T. Suzuki, O. Nakayama, and N. Okamoto, "Partial oxidation of methane to nitrogen free synthesis gas using air as oxidant," Catalysis Surveys From Asia, vol. 16, pp. 75-90, 2012.

[65] K. S. Cha, H. S. Kim, B. K. Yoo et al., "Reaction characteristics of two-step methane reforming over a $\mathrm{Cu}$-ferrite/Ce- $\mathrm{ZrO}_{2}$ medium," International Journal of Hydrogen Energy, vol. 34, no. 4, pp. 1801-1808, 2009.
[66] K. S. Cha, B. K. Yoo, H. S. Kim et al., "A study on improving reactivity of $\mathrm{Cu}$-ferrite $/ \mathrm{ZrO}_{2}$ medium for syngas and hydrogen production from two-step thermochemical methane reforming," International Journal of Energy Research, vol. 34, no. 5, pp. 422-430, 2010.

[67] K. S. Go, S. R. Son, S. D. Kim, K. S. Kang, and C. S. Park, "Hydrogen production from two-step steam methane reforming in a fluidized bed reactor," International Journal of Hydrogen Energy, vol. 34, no. 3, pp. 1301-1309, 2009.

[68] L. F. de Diego, M. Ortiz, F. García-Labiano, J. Adánez, A. Abad, and P. Gayán, "Synthesis gas generation by chemical-looping reforming using a Nibased oxygen carrier," in Proceedings of the 9th International Conference on Greenhouse Gas Control Technologies (GHGT-9), vol. 1, pp. 3-10, Washington DC, USA, November 2008.

[69] L. F. de Diego, M. Ortiz, F. García-Labiano, J. Adánez, A. Abad, and P. Gayán, "Hydrogen production by chemical-looping reforming in a circulating fluidized bed reactor using Ni-based oxygen carriers," Journal of Power Sources, vol. 192, no. 1, pp. 2734, 2009.

[70] M. Rydén, M. Johansson, A. Lyngfelt, and T. Mattisson, "NiO supported on $\mathrm{Mg}-\mathrm{ZrO}_{2}$ as oxygen carrier for chemical-looping combustion and chemical-looping reforming," Energy and Environmental Science, vol. 2, no. 9, pp. 970-981, 2009.

[71] M. Ortiz, L. F. de Diego, A. Abad, F. García-Labiano, P. Gayán, and J. Adánez, "Hydrogen production by auto-thermal chemical-looping reforming in a pressurized fluidized bed reactor using Ni-based oxygen carriers," International Journal of Hydrogen Energy, vol. 35, no. 1, pp. 151-160, 2010.

[72] T. Pröll, J. Bolhàr-Nordenkampf, P. Kolbitsch, and H. Hofbauer, "Syngas and a separate nitrogen/argon stream via chemical looping reforming-a $140 \mathrm{~kW}$ pilot plant study," Fuel, vol. 89, no. 6, pp. 1249-1256, 2010.

[73] M. Ryden and P. Ramos, " $\mathrm{H}_{2}$ production with $\mathrm{CO}_{2}$ capture by sorption enhanced chemical-looping reforming using $\mathrm{NiO}$ as oxygen carrier and $\mathrm{CaO}$ as $\mathrm{CO}_{2}$ sorbent," Fuel Processing Technology, vol. 96, pp. 27-36, 2012.

[74] M. Ortiz, L. F. de Diego, A. Abad, F. Garcia-Labiano, P. Gayan, and J. Adanez, "Catalytic activity of Ni-based oxygen-carriers for steam methane reforming in chemical-looping processes," Energy \& Fuels, vol. 26, no. 2, pp. 791-800, 2012.

[75] O. Nakayama, N. Ikenaga, T. Miyake, E. Yagasaki, and T. Suzuki, "Production of synthesis gas from methane using lattice oxygen of $\mathrm{NiO}-\mathrm{Cr}_{2} \mathrm{O}_{3}$ - MgO complex oxide," Industrial and Engineering Chemistry Research, vol. 49, no. 2, pp. 526-534, 2010.

[76] C. Dueso, M. Ortiz, A. Abad et al., "Reduction and oxidation kinetics of nickel-based oxygen-carriers for chemical-looping combustion and chemical-looping reforming," Chemical Engineering Journal, vol. 188, pp. 142-154, 2012. 

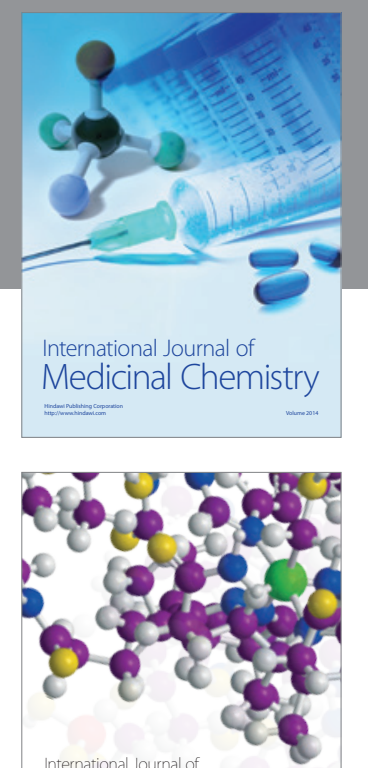

\section{Carbohydrate} Chemistry

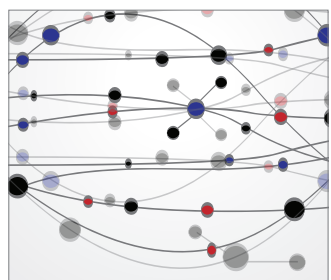

The Scientific World Journal
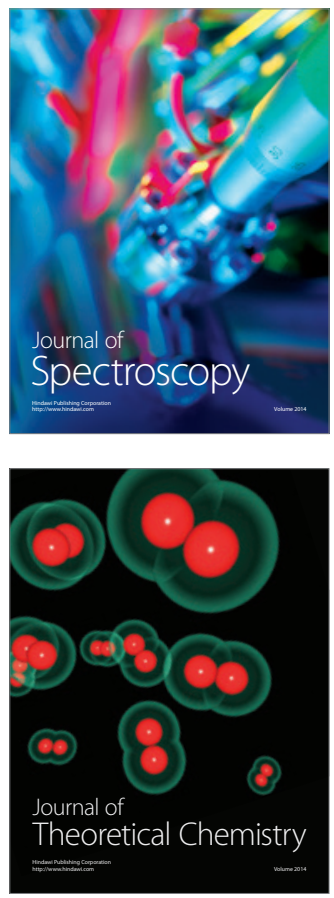
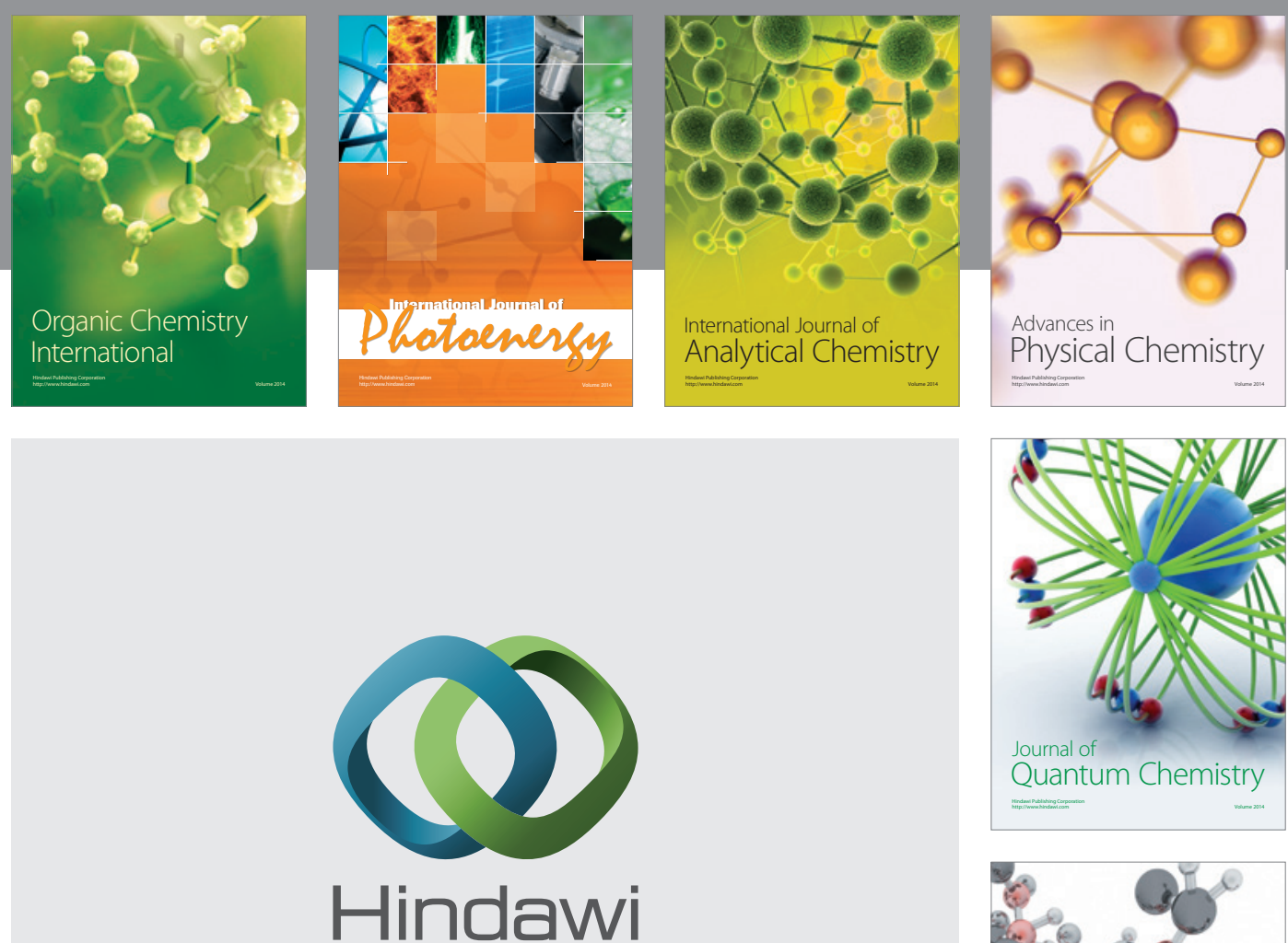

Submit your manuscripts at

http://www.hindawi.com

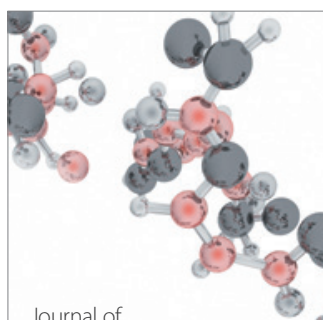

Analytical Methods

in Chemistry

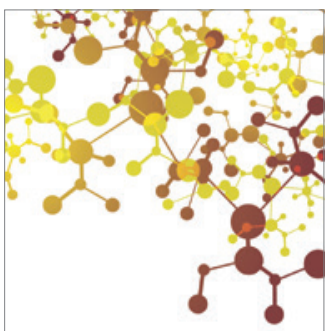

Journal of

Applied Chemistry

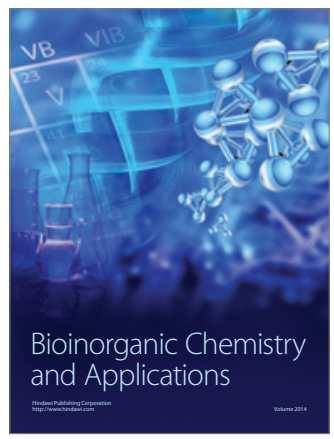

Inorganic Chemistry
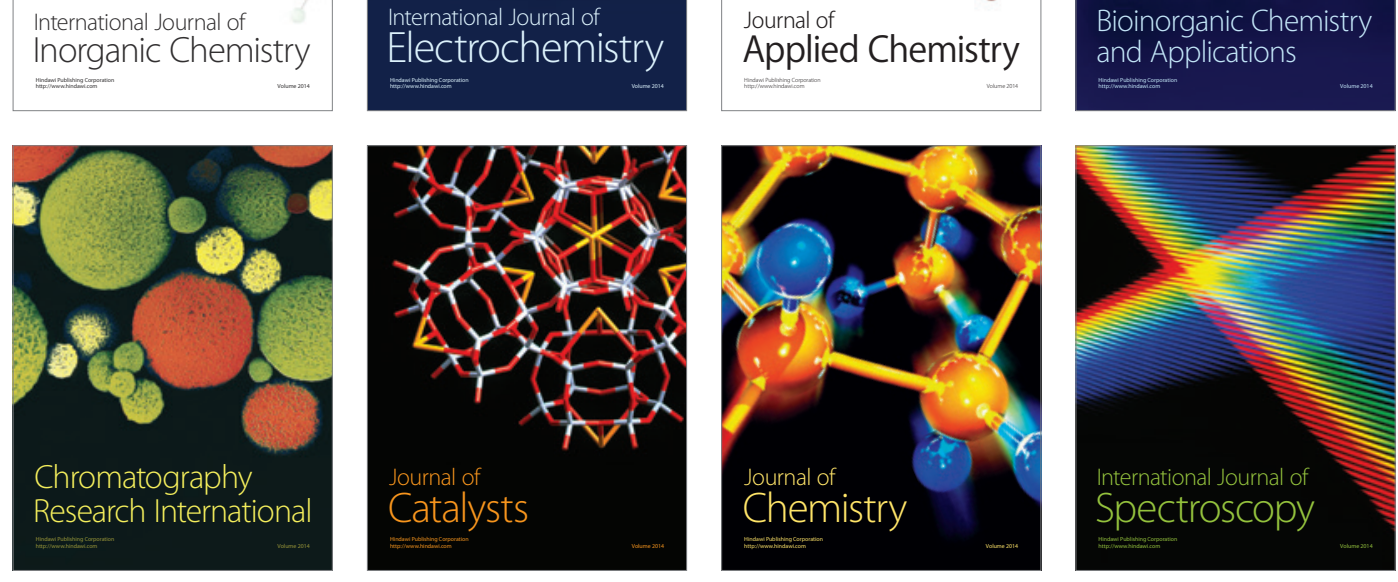